\title{
Identification of Student (Santri) Problems on Islamic Boarding School (Pondok Pesantren)
}

\author{
Ari Khusumadewi ${ }^{1 *}$ \\ ${ }^{1}$ Guidance and Counseling, Universitas Negeri Surabaya, Surabaya, Indonesia \\ *Corresponding author. Email: arikhusumadewi@unesa.ac.id.
}

\begin{abstract}
This research is motivated by the various problems experienced by students on Pondok Pesantren. With the number of students reaching thousands with an unbalanced number of caregivers, the problem is not handled optimally. The policy of the Islamic boarding school regarding the curriculum used makes each Islamic boarding school different. Pesantren as an educational institution has one characteristic that distinguishes it from other educational institutions. The values of Islamic boarding schools that frame the life of social interaction between Kiai, Ustadz, and Santri are the distinguishing characteristics in question. So the problems experienced by students will be different. This study aims to identify the problems experienced by students both in personal, learning, social, and career problems so that it is hoped that they will be able to help plan solutions to the problems faced. This study uses a literature study method that analyzes various reference sources. The data analysis technique used is content analysis, which is a technique used to analyze and understand the text. The results of this study are to explain the various problems faced by students in Islamic boarding schools, their characteristics.
\end{abstract}

Keywords: Student Problems, Islamic Boarding School

\section{INTRODUCTION}

Pondok Pesantren is a religious institution that aims to spread the religion of Islam through education and teaching and develop it which has existed for a long time [1]. Islamic boarding schools have an important role to keep up with the times. In following the developments of the times, Islamic boarding schools not only develop diniyah knowledge but also develop sciences according to the times.

Islamic Boarding School as an Islamic educational institution has developed its form by following the changing times and the impact of advances in science and technology. Thus, many Islamic Boarding Schools teach formal education and other science and technology and add the name to "Modern Islamic Boarding School". Pesantren is an institution that can be said to be a manifestation of the development process of the Islamic education system which also requires innovation in education, not only Diniyah education but also teaching formal education.

Pesantren as an educational institution has one characteristic that distinguishes it from other educational institutions. Islamic boarding school values that frame the life of social interaction between Kiai, Ustadz, and Santri are the distinguishing characteristics in question [2]. The globalization and modernization movements are two sides of a coin that has entered the boarding schools. This presents quite an extraordinary challenge for Pesantren. On the one hand, Islamic boarding schools must maintain their Pesantren traditions as "original" or "indigenous" Indonesian institutions [3], but on the other hand, Pesantren cannot avoid globalization and modernization with all the products they offer. This challenge indirectly creates major changes in Pesantren. Many Islamic boarding schools have finally opened themselves up to modern and formal learning programs such as madrasas, schools, and even universities. The curriculum contained in modern Pesantren can be divided into four basic areas: religious education (ngaji), character development, vocational skills training, and general education (schools) [4]. The special characteristics of Islamic boarding schools include student demographics, age, gender, teacher competence, Pesantren values, Pesantren culture, student problems, diversity of student characteristics, and so on [5][8]

Interviews conducted by researchers to the principle of SMA Al Muqadasah Ponorogo (a Pesantren-based school) 
stated that in the school there were no BK teachers because all students there were good and had never had problems. that $35 \%$ of students need assistance in a career field that varies between career planning and career decision making. This also happened in MA Wachid Hasyim Pasuruan where the Pesantren-based school, in general, had student problems in the career field and had not been handled optimally due to the limitations of Guidance and Counseling teachers because the data obtained were incomplete. The same condition also occurred in the Tebuireng Islamic boarding school, the manager said that the problems experienced were mostly learning problems, but they did not have definite data.

So that this research is expected to be able to see in detail the problems experienced by students to facilitate the followup process on these problems. Problems that occur in students will hinder the development of students and interfere with their learning process. The Tebuireng Islamic Boarding School is one of the oldest educational institutions in East Java with thousands of graduates every year. This Islamic boarding school has also scored important figures in this country. By understanding the problems of students more deeply, it is hoped that will help improve the quality of students so that students become strong and independent individuals in their lives.

According to the Big Indonesian Dictionary (KBBI), the word "santri" has at least two meanings. The first meaning is a person who studies Islam, and the second meaning is a person who worships sincerely or is pious. Santri has been used to refer to people or people who are currently or have deepened the teachings of Islam in Islamic boarding schools. The word "Pesantren" is believed by some to be the origin of the term "santri."

In this study, students in the adolescent age range had the same characteristics as children their age. Joseph [9] shows that most teenagers say that they want someone they can trust, someone they can talk to, someone they can rely on. Teenagers are also no longer just asking for friends of the same sex. Interest in the opposite sex increases during adolescence. Thus, at the end of adolescence, teenagers often prefer the opposite sex as friends even though they continue to be friends with several same-sex friends. Because teenagers understand what is expected of their friends, they insist on choosing their friends without adult intervention.

\section{METHOD}

This study uses a literature study method by comparing research results to answer research questions and identify new approaches [10]-[12], which means that data are taken from various literature sources such as books, articles, and appropriate references. This is a type of literature study that contains research results that are in accordance with the research problem.

Literature study serves to build concepts or theories that become the basis of studies in research. After all the data has been collected, the next step is to analyze the data so that a conclusion is obtained [13]. Literature study can also be interpreted as a series of activities related to library data collection methods, reading and recording, and processing research materials. The data collection method in this research is documentation, namely the collection of data and information from several relevant pieces of literature. This means that researchers research and/or explore several journals, books, and documents (both printed and electronic) as well as sources of data and/or other information deemed relevant to the research or study. The data in this study are secondary data derived from research results that have been published in various indexed journals. Content analysis is a research technique for making replication and conclusions from texts (or other meaningful material) to the context of their use by comparing and looking at the similarities of problematic students in Islamic boarding schools.

The data analysis technique used is content analysis, which is the technique used to analyze and understand the text. Content analysis is a research technique for making replication and inferences from text (or other meaningful material) to the context in which it is used. Content analysis involves specific procedures, as content analysis research techniques provide new insights, increase researchers' understanding of certain phenomena, or inform practical actions [14].

\section{RESULT AND DISCUSSION}

The results showed that the description of the problem areas of new students at Darul Ulum Islamic Boarding School was $25 \%$ in the field of health, $15 \%$ of living conditions, recreation and hobbies/hobbies $37 \%$, social-activity life $81 \%$, personal relationships $34 \%$, youth problems $20 \%$, family life $28 \%$, religion and morals $4 \%$, adjustment to school $29 \%$, future and aspirations $76 \%$, adjustment to curriculum $9 \%$. The results of this study state that the new students of the Darul Ulum Islamic Boarding School have the highest percentage of problems in the field of social-activity life [15].

As with the problems at the Al Amanah Junwangi Islamic boarding school, it shows that the problems of students $93.03 \%$ are study habits, $81.48 \%$ are health problems, $71.86 \%$ are problems doing activities in their free time [16]. By using the Problem Check List instrument at the $\mathrm{Ar}$ Raudlatul Ilmiyah Nganjuk Islamic boarding school, it shows that there are 3 aspects of the problem with the highest category, namely (1) aspects of study habits with the highest percentage $(79 \%)$, (2) aspects of health problems with the percentage $(73 \%)$, (3) the problem of free time is the third percentage $(67 \%)$ [17].

The results of the research at the Baitussahbri Islamic boarding school in Aceh showed that the problems experienced by many students were religious and moral problems were in the very problematic category (63\%), recreational hobbies and hobbies were in the problematic category $(46 \%)$, economic problems were in the problematic category ( $43 \%)$, health problems are in the problematic category $(34 \%)$, social life and organizational activities are in the problematic category (29\%), young people's relationships are in the problematic category (29\%), study habits are in the moderately problematic category ( $23 \%)$, there is no problem with personal relationships (mild), adjustment to school is no problem, adjustment to the curriculum is also no problem [18].

It is different with the Tarbiyatul Muballighin Islamic Boarding School where the problem of students is a violation of the rules of the cottage [19]. Another problem is an adjustment, especially for new female students at the modern Islamic boarding school Nurul Izzah Gresik [20].

The variety of problems experienced by students in Islamic boarding schools shows that there is a complexity of 
problems that are not only centered on personal and social problems [21].

The term "santri", according to that opinion, is taken from a word in Sanskrit, namely sastri which means "literate" or "can read". This version is connected with the opinion of C.C. Berg who mentions the term "santri" comes from the word shastri which in Indian means "one who studies the holy scriptures of Hinduism". Sanskrit is the liturgical language of Hinduism, Buddhism, and Jainism, and one of the 23 official languages of India. Sanskrit was once used in the archipelago during the Hindu and Buddhist periods which lasted from the 2nd century AD until the 16th century following the collapse of the Majapahit Kingdom.

The term "santri" can also be interpreted with the meaning of "guarding three things", as written in the book History of the National Movement (2015) by Fajriudin Muttaqin and his friends, namely maintaining "obedience to Allah, maintaining obedience to His Messenger, and maintaining obedience to Allah. relationships with leaders". From Arabic, the origin of the term "santri" can also be studied. The word "santri" consists of four Arabic letters, namely sin, nun, ta', and ro', each of which has its meaning and should be reflected in the attitude of a santri, as quoted from the book Kiai Also Human: Unraveling Plus Minus Pesantren.

Problematic comes from the word problem which can be interpreted as a problem or problem. The problem itself is an obstacle or problem that must be solved, in other words, the problem is a gap between reality and something that is expected well, to achieve maximum results. There is also in the Big Indonesian Dictionary the word Problematic means still causing problems; things that still cause a problem that still cannot be solved [22].

The students' problems are in all their realms, starting from the personal, social, learning, and career realms. Each student experiences different problems depending on their cognitive, psychosocial, resilience, and self-regulation development [15], [23]. Some examples of problems include the problem of lazy learning and reciting [24], difficulties in participating in Pesantren programs such as the use of foreign languages [25], students' compliance with existing regulations [26], students' positive thinking skills [27]. 2012), and the readiness of students to collaborate with the community [28].

The santri problem is not only the learning aspect but also the personal social aspect. This is the similarity of the contents of the articles presented. Therefore it can use the need assessment as guidelines to the planning of helping for santri in Islamic boarding schools based on students' problems. The second equation is the model of assistance provided in the Islamic boarding schools is still in the form of advice, has not touched the therapeutic aspects.

The difference that appears in the problems of santri in Islamic boarding schools is in the category or group of problems. Some Islamic boarding schools have the biggest problems is learning such as how to learn effectively; how to adapt to the learning activity; what should they do to enjoy the learning program; etc. Some have the biggest problems in ideals which show that there is still a confusion of career and future, and others have the biggest problems in how to doing hobbies, they show the need for self-development and how to perform self-development, how to perform catharsis on all activities and psychological conditions of students..

\section{CONCLUSION}

Based on the results of research data shows that the problems experienced by students in Islamic boarding schools are very diverse. This diversity provides opportunities for the development of assistance, especially in the field of guidance and counseling. The assistance provided can be in the form of guidance and counseling services, development of guidance and counseling media, development of peer mentors, and so on. The charismatic power of the Kyai in all forms of santri activities is still very strong in efforts to solve santri problems. These charismatic values are internalized in students as part of an effort to get karomah and the embodiment of sami'na wa atho'na behavior.

\section{REFERENCES}

[1] M. R. Nasir, Mencari Tipologi Format Pendidikan Ideal: Pondok Pesantren di Tengah Arus Perubahan. Pustaka pelajar, 2005.

[2] S. Ma'rufah, A. Matulessy, and I. Noviekayati, "Persepsi terhadap kepemimpinan kiai, konformitas dan kepatuhan santri terhadap peraturan pesantren," Pers. J. Psikol. Indones., vol. 3, no. 02, 2014.

[3] N. Madjid, Bilik-bilik pesantren: sebuah potret perjalanan. Paramadina, 1997.

[4] R. A. Lukens-Bull, "Two sides of the same coin: Modernity and Tradition in Islamic education in Indonesia," Anthropol. Educ. Q., vol. 32, no. 3, pp. 350-372, 2001.

[5] E. P. Sarafino and T. W. Smith, Health psychology: Biopsychosocial interactions. John Wiley \& Sons, 2014.

[6] N. Fatoni, "Kultur Pesantren: Relasi Kiai, Santri, dan Kitab Kuning," IBDA J. Kaji. Islam dan Budaya, vol. 9, no. 2, pp. 165-177, 2011.

[7] M. Thahir, "The role and function of Islamic boarding school: An Indonesian context," TAWARIKH, vol. 5, no. 2, 2014.

[8] M. K. Ashari, "Kompetensi guru pesantren dalam meningkatkan kecerdasan sosial santri: studi multi kasus di pondok pesantren Roudlotul Qur'an dan pondok pesantren Fathul Hidayah Lamongan.” UIN Sunan Ampel Surabaya, 2018.

[9] E. B. Hurlock, Developmental psychology. Tata McGraw-Hill Education, 2001.

[10] M. D. Gall, W. R. Borg, and J. P. Gall, Educational research: An introduction. Longman Publishing, 1996.

[11] I. Korstjens and A. Moser, "Series: Practical guidance to qualitative research. Part 4: Trustworthiness and publishing," Eur. J. Gen. Pract., vol. 24, no. 1, pp. 120-124, 2018.

[12] L. M. O'Dwyer and J. A. Bernauer, Quantitative research for the qualitative researcher. SAGE publications, 2013.

[13] S. Suharsimi Arikunto, "Prosedur penelitian suatu pendekatan praktik," Jakarta: Rineka Cipta, 2010.

[14] K. Krippendorff, Content analysis: An introduction to its methodology. Sage publications, 2018.

[15] E. M. Sari, "Identifikasi Permasalahan Santri Pondok Pesantren Darul Ulum Komplek YPUI Kampung Keuramat Kecamatan Kuta Alam Kota Banda 
Aceh," ETD Unsyiah, 2018.

[16] A. Nabella, "Peta Masalah Santri dan Kesiapan Guru BK di SMA Pondok Pesantren modern AL-Amanah Junwangi, Krian,” J. BK Unesa, vol. 7, no. 3, 2017.

[17] A. T. WAM, "Peta Masalah Santri dan Kesiapan Guru Bk di Pondok Pesantren Ar-Raudlatul Ilmiyah Kecamatan Kertosono Kabupaten Nganjuk,” J. BK UNESA, vol. 7, no. 2, 2017.

[18] Y. Syuhada, "IDENTIFIKASI MASALAH YANG DIHADAPI SANTRI DAN KEBUTUHAN BK DI PONDOK PASANTREN," ETD Unsyiah, 2018.

[19] V. Z. Ningrum, "Perilaku Sosial Santri di Pondok Pesantren Tarbiyatul Muballighin Desa Reksosari Kecamatan Suruh Kabupaten Semarang." UNNES, 2019.

[20] M. Pritaningrum and W. Hendriani, "Penyesuaian diri remaja yang tinggal di Pondok Pesantren Modern Nurul Izzah Gresik pada tahun pertama," $J$. Psikol. Kepribadian dan Sos., vol. 2, no. 3, pp. 134143, 2013.

[21] Y. Hotifah, "Penyelesaian Permasalahan Santri melalui Peer Helping Indigenius," Ilmu Pendidik. J. Kaji. Teor. dan Prakt. Kependidikan, vol. 42, no. 2, 2019.

[22] K. B. B. Indonesia, "Jakarta," Republik Indones., 2011.

[23] Z. Prasetyana and L. I. Mariyati, "Hubungan Antara
Religiusitas Dengan Regulasi Diri Pada Santri Madrasah Diniyah Di Sidoarjo," PSYCHE J. Psikol., vol. 2, no. 2, pp. 76-86, 2020.

[24] F. Fitriah, "Aplikasi Manajemen dalam Meningkatkan Efektivitas Kegiatan Mengaji Santri (Studi Deskriptif di Pondok Pesantren Pagelaran III Cisalak, Subang).” UIN Sunan Gunung Djati Bandung, 2016.

[25] M. Amin, "Upaya Pondok Pesantren Modern Bina Insani Ketapang Susukan Kabupaten Semarang Dalam Meningkatkan Kemahiran Berbicara Bahasa Arab Santri." Universitas Muhammadiyah Surakarta, 2013.

[26] A. P. Wilujeng, "Efektivitas Pelatihan Berfikir Positif Terhadap Kepatuhan Pada Aturan Santri Pondok Pesantren Tebu Ireng Jombang," Skripsi. Malang UIN Maliki Malang, 2010.

[27] L. Rohmah, "Hubungan antara berfikir positif dengan kepatuhan pada aturan: Studi pada santri di Pondok Pesantren Putri Al-Amanah Tambakberas Jombang." Universitas Islam Negeri Maulana Malik Ibrahim, 2012.

[28] A. Bahrudin, “ Pondok Pesantren As-Syar'i Darul Hikam Brebek Dalem Waru Sidoarjo Studi Sejarah dan Aktivitas Sosial Pondok Pesantren As-Syar'i Darul Hikam Terhadap Masyarakat Brebek." UIN Sunan Ampel Surabaya, 2011. 